\author{
Alicja Grześkowiak \\ Wrocław University of Economics \\ e-mail: alicja.grzeskowiak@ue.wroc.pl
}

\title{
AGE AND PERCEPTION OF NON-FINANCIAL WORK ASPECTS BY POLES ${ }^{1}$
}

\begin{abstract}
Summary: The article presents the problem of the co-occurrences of opinions on important non-financial work aspects among people from different age groups reflecting various stages of professional development: career start, phase of attainments, stage of preserving attainments and a rest phase. The study is based on non-metric survey data, which determines the use of adequate research methods. Association analysis is applied in order to identify patterns of responses. The revealed association rules indicate that there are differences in the perception of non-financial work values among respondents from different age intervals.
\end{abstract}

Keywords: work values, categorical data, association rules.

DOI: 10.15611/ekt.2014.3.01

\section{Introduction}

Work plays a significant role in human life. Individuals may assign different relative importance to the various aspects of work, which may result in different work values patterns; furthermore, a range of background factors influencing such an assignment can be indicated, including age [Mottaz 1985]. Aspects of work may be divided into intrinsic (associated with self-actualization), extrinsic (associated with external rewards and benefits) and mixed-type dimensions [Wollack et al. 1971]. Other categorizations are also proposed, e.g. Ros, Schwartz, Surkiss [1999] opt for a classification consisting of intrinsic, extrinsic and social/relational values. A large set of work values covering all the above-mentioned groups is considered in European Values Study (EVS), which gives an opportunity to deal with microdata referring to this topic.

${ }^{1}$ This paper was prepared within the project "Non-metric multivariate data analysis as a tool for study of adults situation in the context of demographic changes" financed by the National Science Centre (Narodowe Centrum Nauki) in Poland. Project number: 2012/05/B/HS4/02499. 
This paper is focused on the work values declared by Poles with respect to age. The system transformation started in 1989 resulted in substantial changes not only in the economic but also in the societal sense. Younger generations grew up in an environment different from their ancestors, which may have had an influence on attitudes and declared values. It should be underlined that EVS includes a set of work aspects including payments. As salaries are already relatively widely discussed in the context of the Polish labour market this paper is oriented towards non-financial aspects, which are analyzed less frequently and therefore are less portrayed and characterized.

The general hypothesis put forward and verified in this paper is that the patterns of the work values indicated by Poles vary across various age intervals since persons at certain age tend to be at a different level of career development. For the purpose of this study, the division into four career levels is applied: starting the career, professional achievements, attainment preservation and the end of the professional activities [Pocztowski 2003, p. 336].

Marody [2012, pp. 70-71] finds out that important characteristics of job are poorly diverse and are not strongly linked to the socio-demographic features of Polish respondents. Hence, the subject of interest of this study is not the level of the importance of each factor separately, but - most of all - the relations and co-occurrences among various non-financial values. The general purpose of the research is to identify and compare association patterns for persons at certain age which are connected with professional career stages. As the EVS data describing work values are binary, detection of association rules is applied to achieve the defined objective.

As the paper includes only one wave of EVS and only one analytical technique is applied, it should be considered as a preliminary analysis and may be a starting point for further research.

\section{Data source and analytical approach}

As already mentioned, the analysis is carried out on the basis of data from European Values Study. This research project is a longitudinal survey which took place in 1981, 1990, 1999 and 2008 so far, and Poland participated in the last three waves. The collected data give the possibility to consider the regularities for each year separately or to perform the analyses of the evolution of the values. Nevertheless, six new categories concerning work aspects were added in 2008 questionnaire as compared with previous versions applied in Poland. Hence, the latest study gives a more comprehensive insight into the considered issues and is not fully comparable with previous surveys. For this reason, the present paper refers only to the most recent data giving the most up-to-date picture of the non-financial aspects perception in a broader sense than the one possible based on the previous surveys. Thus, the analysis is based on the data from the last (4th) round of the EVS survey ${ }^{2}$, which took place in 2008. It

${ }^{2}$ EVS (2010), European Values Study 2008: Poland (EVS 2008). GESIS Data Archive, Cologne. ZA4769 Data file Version 1.1.0, doi:10.4232/1.10164. 
is worth mentioning that this year was quite particular for the Polish labour market. Firstly, according to the Eurostat Labour Force Survey, the unemployment rate was equal to $7.1 \%$, which was the lowest level in the ten-year period. Moreover, the unemployment rate declined systematically from 2002 and this decrease was rather profound - 12.9 percentage points in eight years. Secondly, positive changes occurred when regarding the employment rate (age 15-64) which was equal to 59.2\% and its upward trend was observed for more than ten years. Labour market participants had some grounds for optimism.

The analysis explores answers to the question "Here are some aspects of a job that people say are important. Please look at them and tell me which ones you personally think are important in a job?" [European Values... 2008, p. 4]. Respondents had to indicate statements describing important aspects of their work, including intrinsic, extrinsic and relational ones. Responses resulted in binary a representation (mentioned, not mentioned). It should be underlined that the most important factor in Poland is "good pay" (93.4\%) but it is not under consideration in this study. The list of the non-financial aspects included in European Values Study Master Questionnaire is as follows [European Values... 2008, pp. 4-5]:

- an opportunity to use initiative,

- a job in which you feel you can achieve something,

- a responsible job,

- a job that is interesting,

- a job that meets one's abilities,

- learning new skills,

- have a say in important decisions,

- useful job for society,

- meeting people,

- pleasant people to work with,

- people treated equally at the workplace,

- family friendly,

- not too much pressure,

- good job security,

- good hours,

- generous holidays.

Two other factors were added to the Polish version of the EVS questionnaire:

- big chances for promotion,

- job respected by others.

The above presented list is arranged starting with the values which seem to have an intrinsic character, then societal/relational values and finally extrinsic aspects. The number of individuals interviewed in this wave of the survey in Poland is equal to $N=1510$.

According to the research hypothesis the perception of the importance of work aspects may depend on the age of the respondents. There is a substantial relation between age and phases of professional career but there is no universal model describ- 
ing it; on the contrary, there are many concepts of career development [Pocztowski 2003, pp. 338-339]. For the purpose of the work, the following division is used [cf. Pocztowski 2003, p. 336]:

- persons up to 29 years (stage of beginning professional career),

- persons 30-44 years (stage of achievements),

- persons 45-64 years (stage of preserving achievements),

- persons $65+$ (stage of ending professional activities and beginning retirement/ rest).

The above-mentioned partition is a theoretical approach and is not necessarily adequate in individual cases. However, as a generalization it can give a reason for a comparative study of work aspects perception.

The list of non-financial aspects of work consists of many elements, which leads to a multivariate approach in the analysis. Interdependencies among categorical data are often examined by the multivariate correspondence analysis or log-linear modeling but applications of these methods may be limited in the case of many variables due to problems with a graphical representation or sparse matrixes. Another technique that allows assessing the relationships among responses is one of unsupervised learning methods based on finding association rules. Association rules mining aims at discovering interesting relationships in large datasets [Cios et al. 2007, p. 289]. Although the best-known application of this approach is the market-basket analysis, it can be also used to analyze survey data [Łapczyński 2014, p. 45]. An association rule is expressed as an implication. In our case it can be described as "if work aspect A, then work aspect B" statement and may help to detect which aspects are frequently mentioned together by respondents. In this notation, elements $\mathrm{A}$ and $\mathrm{B}$ are called antecedent and consequent, respectively. The quality of a rule in the sense of its strength and certainty is evaluated by support and confidence measures [Cios et al. 2007, p. 290]. In general terms, support of the whole rule is the probability of conjunction of $\mathrm{A}$ and $\mathrm{B}$, i.e., and confidence is the conditional probability of $\mathrm{B}$ given A, i.e. [Larose 2013, pp. 187-189]. These probabilities are estimated, so in our case support can be expressed as the relation of individuals who answered both A and B to the total number of respondents:

$$
\text { support }=\frac{n_{A B}}{N},
$$

where: $n_{A B}$ - number of respondents who indicated both A and B work aspects, $N$ - total number of respondents.

Confidence reflects how many of the individuals that indicated A also indicated B:

$$
\text { confidence }=\frac{n_{A B}}{n_{A}},
$$

where: $n_{A B}$ - number of respondents who indicated both $\mathrm{A}$ and $\mathrm{B}$ work aspects, $n_{\mathrm{A}}-$ number of respondents who indicated the aspect $\mathrm{A}$. 
Measures (1) and (2) are usually expressed as percentages and used to find interesting rules satisfying minimum values of support and confidence defined by the researcher [Cios et al. 2007, p. 290]. An additional quality indicator used in this study is a so-called lift (or interest) given by the formula:

$$
\text { lift }=\frac{P(A \cap B)}{P(A) P(B)} .
$$

Lift measure compares the co-occurrence of $\mathrm{X}$ and $\mathrm{Y}$ to the expected value under the condition of being statistically independent $($ lift $=1)$. The result greater than 1 indicates that the occurrences of two items are dependent on one another, which is also called a positive correlation [Han, Kamber, Pei 2006, p. 261], wherein the higher value, the bigger degree of dependence. An overview of other quality measures for association rules can be found in Łapczyński [2014, pp. 12-16].

In this study, the following minimal thresholds of measures are assumed: support $=40 \%$ and confidence $=90 \%$. The search is limited to the rules with one antecedent and one consequent only. Association rules satisfying the criteria are visualized on figures presenting the importance of the antecedent, the consequent and the whole rule by the size, the colour and the thickness of elements.

\section{Results of the analysis}

Association rules found in the youngest age group are shown in Figure 1 and Table 1. The highest lift rate is observed in the case of rules family friendly people treated equally and have a say people treated equally. Figure 1 gives an insight into the

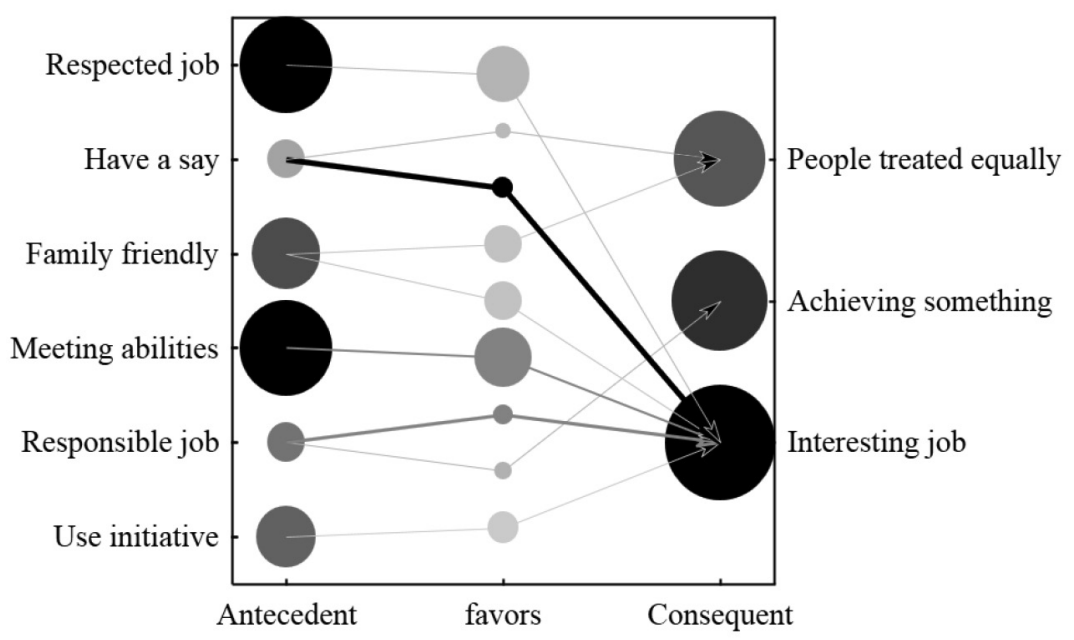

Figure 1. Visualization of the association rules for the age group 29 or below

Source: own study. 
configuration of co-occurrences. The size and the colour intensity of the circles on the left and right side of the picture reflect the relative frequencies of particular aspects while the circles in the middle depict the support of the association rules. The thickness and the colour intensity of the arrows correspond to the relative confidence of the rules.

The association rules with the highest support combine intrinsic aspects of work as a job which is interesting, respected and that meets one's abilities. Next important aspects included in the association rules are the possibility to achieve something and the state of being treated equally. The highest confidence is ascribed to the relation between an opportunity to participate in crucial decisions and having an interesting job. The importance of the value interesting job should be underlined as it is the consequent for all distinguished antecedents.

Table 1. Association rules and their characteristics for the age group 29 or below

\begin{tabular}{|l|l|c|c|c|}
\hline \multicolumn{1}{|c|}{ Antecedent } & \multicolumn{1}{c|}{ Consequent } & Support (\%) & Confidence (\%) & Lift \\
\hline Family friendly & People treated equally & 52.76 & 90.54 & 1.25 \\
\hline Have a say & People treated equally & 44.88 & 90.48 & 1.25 \\
\hline Responsible job & Achieving something & 45.41 & 91.05 & 1.23 \\
\hline Have a say & Interesting job & 46.98 & 94.71 & 1.20 \\
\hline Responsible job & Interesting job & 46.19 & 92.63 & 1.17 \\
\hline Meeting abilities & Interesting job & 60.10 & 92.34 & 1.17 \\
\hline Use initiative & Interesting job & 50.66 & 90.61 & 1.15 \\
\hline Family friendly & Interesting job & 52.76 & 90.54 & 1.15 \\
\hline Respected job & Interesting job & 59.06 & 90.73 & 1.15 \\
\hline
\end{tabular}

Source: own computations with Statistica (version 10).

The association rules revealed for the age interval 30-44 are given in Figure 2 and in Table 2.

Both extrinsic and intrinsic work values are pointed out as substantial by the respondents from this age group. The association rules are more varied in nature than those detected for people starting their career. Among consequents the most important are job security and pleasant people to work with. The highest support is observed between a job that meets one's abilities and job security. An interesting dissimilarity is seen when a comparison with the younger group is performed. The association rules with the highest support have the same antecedents but the consequent is different - an interesting job for the youngest and job security for those aged $30-44$. It is worth mentioning that a relatively high support occurs between chances for promotion and regarding job as interesting. The highest confidence is characteristic for the rule linking the possibility to have influential opinions and possessing an interesting job. However, the confidence levels differ only slightly, so they do not allow distinguishing the association rules essentially. 


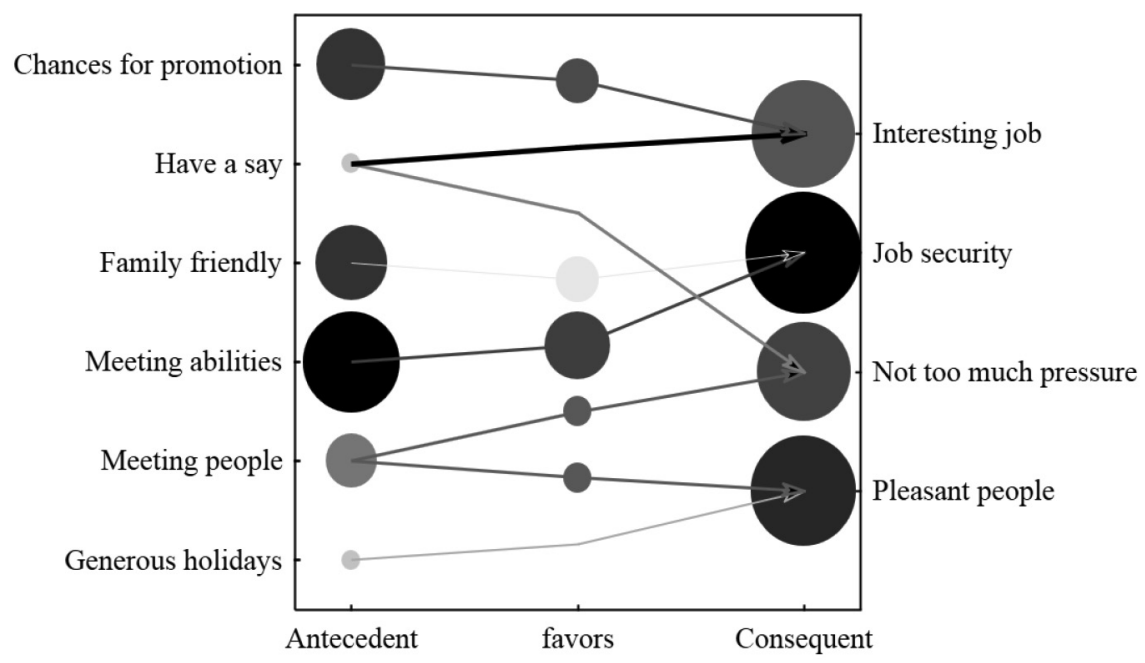

Figure 2. Visualization of the association rules for the age group 30-44

Source: own computations with Statistica (version 10).

Table 2. Association rules and their characteristics for the age group 30-44

\begin{tabular}{|l|l|c|c|c|}
\hline \multicolumn{1}{|c|}{ Antecedent } & \multicolumn{1}{c|}{ Consequent } & Support (\%) & Confidence (\%) & Lift \\
\hline Meeting people & Not too much pressure & 47.68 & 91.15 & 1.28 \\
\hline Have a say & Not too much pressure & 40.33 & 91.36 & 1.28 \\
\hline Have a say & Interesting job & 40.6 & 91.98 & 1.24 \\
\hline Chances for promotion & Interesting job & 51.77 & 91.35 & 1.23 \\
\hline Generous holidays & Pleasant people & 40.05 & 90.74 & 1.21 \\
\hline Meeting people & Pleasant people & 47.68 & 91.15 & 1.21 \\
\hline Meeting abilities & Job security & 58.04 & 91.42 & 1.16 \\
\hline Family friendly & Job security & 51.77 & 90.04 & 1.14 \\
\hline
\end{tabular}

Source: own computations with Statistica (version 10).

Association rules uncovered for the persons at the career stage labeled preserving achievements are presented in Table 3 . As there are only two rules satisfying the imposed criteria, no visualization is provided. Persons aged 45-65 tend to combine such work values as an opportunity to learn new skills, using one's qualifications and a high job security. A stronger rule both in the sense of support and confidence is the one including the adequacy for the abilities.

Nine vital association rules for the oldest group are shown in Figure 3 and Table 4. 
Table 3. Association rules and their characteristics for the age group 45-64

\begin{tabular}{|l|l|c|c|c|}
\hline \multicolumn{1}{|c|}{ Antecedent } & \multicolumn{1}{c|}{ Consequent } & Support (\%) & Confidence (\%) & Lift \\
\hline Meeting abilities & Job security & 56.84 & 91.90 & 1.15 \\
\hline Learning new skills & Job security & 46.82 & 91.35 & 1.15 \\
\hline
\end{tabular}

Source: own calculations with Statistica (version 10).

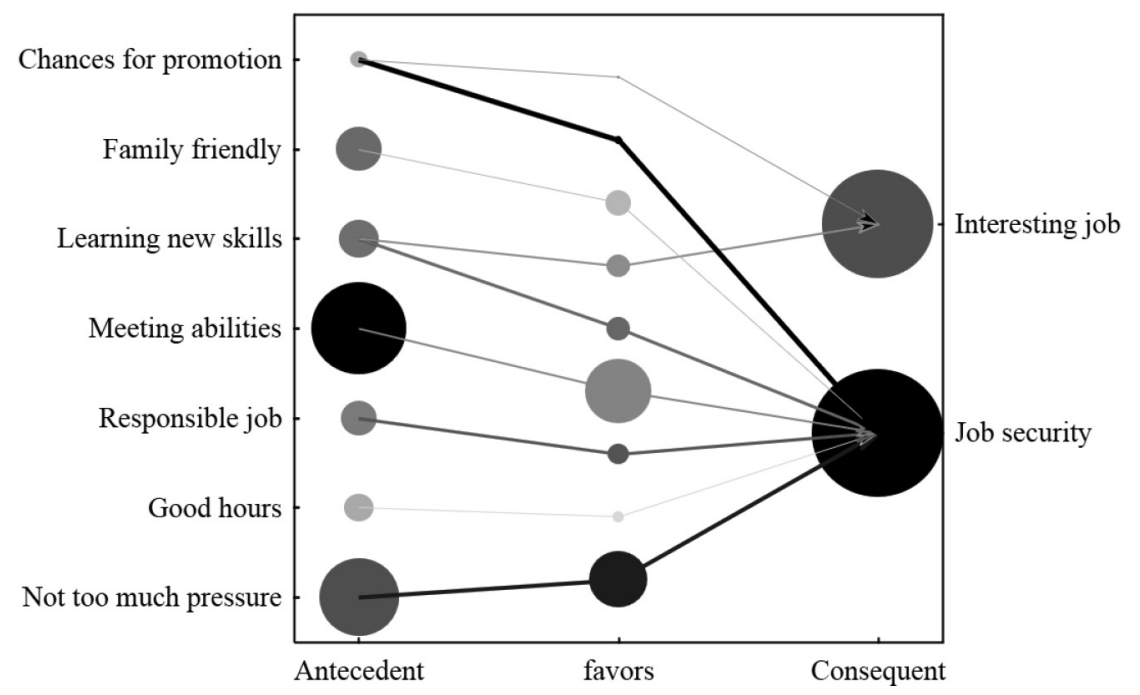

Figure 3. Visualization of association rules for the age group $65+$

Source: own computations with Statistica (version 10).

Table 4. Association rules and their characteristics for the age group 65+

\begin{tabular}{|l|l|c|c|c|}
\hline \multicolumn{1}{|c|}{ Antecedent } & \multicolumn{1}{c|}{ Consequent } & Support (\%) & Confidence (\%) & Lift \\
\hline Learning new skills & Interesting job & 46.70 & 92.52 & 1.22 \\
\hline Chances for promotion & Interesting job & 40.57 & 91.49 & 1.20 \\
\hline Chances for promotion & Job security & 41.98 & 94.68 & 1.15 \\
\hline Not too much pressure & Job security & 58.02 & 93.89 & 1.14 \\
\hline Responsible job & Job security & 46.23 & 93.33 & 1.13 \\
\hline Learning new skills & Job security & 47.17 & 93.46 & 1.13 \\
\hline Meeting abilities & Job security & 60.85 & 92.14 & 1.12 \\
\hline Family friendly & Job security & 47.64 & 90.99 & 1.10 \\
\hline Good hours & Job security & 42.92 & 90.10 & 1.09 \\
\hline
\end{tabular}

Source: own calculations with Statistica (version 10). 
There are only two consequents, i.e. job security and interesting job, representing two work values different in nature: extrinsic and intrinsic. The highest support measures are observed between the feeling that a job stays in accordance with the abilities and job security as well as between not too much pressure and job security. Moreover, job security is the consequent for all the distinguished antecedents while, interesting job is preceded only by two factors chances for promotion and learning new skills but with relatively high lift measures.

\section{Conclusions}

The interdependencies of opinions on the non-financial work aspects are different in considered age groups, although some elements of high importance may be noted repetitive, i.e.: interesting job and job security. It should be underlined that association rules differ more in the sense of support than in the confidence level. Moreover, the number of association rules fulfilling the imposed criteria is the same in three career stage categories (nine association rules found), but they are different in nature. Only two rules are important for the age group 45-64.

Some general regularities can be pointed out. In the case of the youngest group, the dominance of intrinsic values may be observed. A more balanced pattern is detected for persons in the next phase of career development (age 30-44) as some intrinsic, extrinsic and societal values are combined. According to the answers given by the persons at the stage of preserving achievements (age 45-64), there are no important associations rules between societal and other values, the only two vital associations are between intrinsic and extrinsic work aspects. More rules including both intrinsic and extrinsic values are disclosed in the oldest group with a long lifespan professional experience. The youngest and the oldest groups have dominating consequents of association rules. For those who start their professional careers it is interesting job while for those finishing it - job security. One of the most important aspects which is associated with other factors is a job that meets one's abilities. The youngest combine it with interesting job while the others with job security.

The application of association rules reveals that there are differences in the interdependencies among crucial work values perception in relation to age intervals. It seems that nonfinancial work values gain bigger importance in Poland with the progress of the economic development, especially when a comparison between 1990 and 2008 survey results is made [Marody 2012, p. 70]. On the other hand, creating better work conditions should contribute to economic development.

Although the objective of this paper is mostly cognitive in nature, some potential areas of practical implementation of the results may be pointed out as a kind of general hints supporting guidelines for motivation and incentives adequate for employees who are at various stages of their careers. 


\section{References}

Cios K.J., Pedrycz W., Swiniarski R.W, Kurgan L.A., 2007, Data Mining: A Knowledge Discovery Approach, Springer, New York.

European Values Study EVS 2008 Master Questionnaire, Tilburg University \& Leibniz Institute for Social Sciences,

http://info1.gesis.org/dbksearch/file.asp?file=ZA4800_q.pdf (accessed: 06.06.2014).

Han J., Kamber M., Pei J., 2006, Data mining: concepts and techniques, Morgan Kaufmann, San Francisco.

Larose D.T., 2013, Odkrywanie wiedzy z danych. Wprowadzenie do eksploracji danych, Wydawnictwo Naukowe PWN, Warszawa.

Łapczyński M., 2014, Analiza asocjacji i sekwencji w badaniach marketingowych, Wydawnictwo Uniwersytetu Ekonomicznego w Krakowie, Kraków.

Mottaz C.J., 1985, The relative importance of intrinsic and extrinsic rewards as determinants of work satisfaction, The Sociological Quarterly, vol. 26, issue 3, pp. 365-385.

Marody M., 2012, Dynamika postaw wobec pracy [in:] A. Jasińska-Kania, Wartości i zmiany. Przemiany postaw Polaków w jednoczacej się Europie, Wydawnictwo Naukowe Scholar, Warszawa.

Pocztowski A., 2003, Zarzadzanie zasobami ludzkimi, PWE, Warszawa.

Ros M., Schwartz S.H., Surkiss S., 1999, Basic individual values, work values, and the meaning of work, Applied Psychology, vol. 48(1), pp. 49-71.

Wollack S., Goodale J.G., Wijting J.P., Smith P.C., 1971, Development of the survey of work values, Journal of Applied Psychology, vol. 55(4), pp. 331-338.

\section{WIEK A POSTRZEGANIE NIEFINANSOWYCH WARUNKÓW PRACY PRZEZ POLAKÓW}

Streszczenie: Artykuł podejmuje problematykę współwystępowania opinii o ważnych niefinansowych warunkach pracy wśród osób z różnych grup wieku, znajdujących się w odmiennych fazach rozwoju zawodowego: rozpoczynania kariery, etapu osiągnięć, stadium utrzymywania osiągnięć i odpoczynku. W analizie wykorzystano dane sondażowe o charakterze niemetrycznym, co warunkuje wykorzystanie odpowiednich metod badawczych. W celu identyfikacji wzorców odpowiedzi zastosowano analizę asocjacji. Wyznaczone reguły asocjacyjne wskazują, że występują różnice w postrzeganiu niefinansowych warunków pracy przez osoby w różnym wieku.

Słowa kluczowe: wartości pracy, dane niemetryczne, reguły asocjacyjne. 